\title{
SINDROME DE BROWN: ASPECTOS CLÍNICOS E DIAGNÓSTICO
}

\author{
João Augusto Carvalho Bittencourt ${ }^{1}$; Thiana de Oliveira Kaé ${ }^{2}$
}

\section{Resumo}

\section{Introdução:}

A Síndrome de Brown é uma patologia que caracteriza-se, essencialmente, por uma limitação da elevação do olho em adução. Foi primeiramente descrita por Harold Brown, em 1950, tendo como causa básica a anormalidade da bainha do músculo oblíquo superior. Pode apresentar etiologia congênita, com encurtamento da bainha do tendão, ou adquirida, caracterizando processos inflamatórios e iatrogênicos. Este trabalho tem como objetivo elucidar os principais aspectos clínicos e complementar os poucos dados atualmente existentes na literatura sobre essa patologia.

\section{Método:}

Este trabalho foi realizado por meio de pesquisa de artigos realizada nos principais meios científicos(UpToDate, Scielo, Lilacs), complementado com revistas de congressos internacionais de oftalmologia.

\section{Resultados:}

A Síndrome de Brown é também conhecida como "Síndrome da Bainha do Tendão do Oblíquo Superior", uma forma de estrabismo vertical restritivo, podendo ser unilateral ou bilateral, congênito ou adquirido, sendo a forma congênita presente na maioria dos casos. Possui incidência de 1/500, sendo monocular a mais prevalente. Esse tipo de estrabismo é devido a uma interação anômala entre a tróclea e o tendão do músculo oblíquo superior. O quadro clínico clássico é composto por: (1) severa limitação na elevação em adução; (2) leve depressão do olho em adução; (3) divergência em supraversão; (4) teste de dução passiva positivo. Segundo Horta Barbosa, há limitação do olhar em todo campo superior

\footnotetext{
${ }^{1}$ Acadêmico do $6^{\circ}$ semestre do curso de medicina da Universidade Federal de Pelotas

${ }^{2}$ Acadêmica do $11^{\circ}$ semestre do curso de medicina da Universidade Federal de Pelotas
} 
na maioria dos casos. Deve-se ressaltar que nem todos os pacientes apresentam todos os sintomas descritos anteriormente.

\section{Conclusões:}

Concluímos, dessa maneira, que há necessidade de outras publicações na literatura médica sobre o assunto, com o intuito de elucidar melhor dados de prevalência e aspectos clínicos. Desse modo, nossos médicos terão maior conhecimento sobre o assunto e mínimas dificuldades para realizar o diagnóstico. Cabe ressaltar aqui que o tratamento tem indicação cirúrgica nos seguintes casos: hipotrofia na posição primária, torcicolo ou depressão do olho em adução. 